\title{
Performing with Plants in the Ob-scene Anthropocene
}

\section{ANNETTE ARLANDER}

\begin{abstract}
Is there a way for the anthropocentric and anthropomorphic art form par excellence, the theatre, or performance art for that matter, to expand beyond their human and humanist bias? Is the term Anthropocene in any way useful for theatre and performance studies or performance-as-research?

In the anthology Anthropocene Feminism (Grusin 2017) Rosi Braidotti proposes four theses for a posthumanist feminism: 1) feminism is not a humanism, 2) anthropos is off-center, 3) zoe is the ruling principle, 4) sexuality is a force beyond gender. These assertions can undoubtedly be put on stage, but do they have relevance for developing or understanding performance practices off-stage and off-center, such as those trying to explore alternative ways and sites of performing, like performing with plants?

In this text, I examine Braidotti's affirmative theses and explore their usefulness with regard to performance analysis, use some of my experiments in the artistic research project "Performing with plants" as examples, and consider what the implications and possible uses of these theses are for our understanding of performances with other-than-human entities, which we share our planet with.
\end{abstract}

\section{KEYWORDS}

Performance, theatre, non-human, posthuman, performance analysis, Anthropocene feminism, Braidotti, anthropocentric, anthropomorphic, performing with plants 


\section{Performing with Plants in the Ob-scene Anthropocene}

What else does the current debate on the Anthropocene bring into performance, besides "empty" stages with sand, smoke or water performing as representations of post-apocalyptic landscapes? Is there another way for the anthropocentric and anthropomorphic art form par excellence, the theatre, or performance art for that matter, to expand beyond their human and humanist bias? Is the term in any way useful for theatre and performance studies or performance-asresearch? And what has this to do with performing with plants? Could exploring ways of performing with plants mitigate the anthropocentrism of performance art?

I.

In the anthology Anthropocene Feminism", Rosi Braidotti "provides a cartography of the intersections between feminism and the posthuman predicament" by suggesting that feminism is not a humanism; that Anthropos has been de-centered, that nonhuman life, zoe, rather than bios, should be our concern, and "that sexuality is a force beyond, beneath, and after gender."

Her four theses for a posthumanist feminism: 1) feminism is not a humanism, 2) anthropos is off-center, 3) zoe is the ruling principle, 4) sexuality is a force beyond gender, can undoubtedly be put on stage and discussed on stage, but do they have relevance for developing or understanding performance practices off-stage and off-center? Such as practices trying to explore alternative ways and sites of performing, like performing with plants? In this text we will examine Braidotti's affirmative theses and explore their usefulness with the help of some experiments in an artistic research project called Performing with Plants, thus considering the implications of these theses for our understanding of performances with other-than-human entities that we share our planet with.

Besides the feminist critique of the notion of the anthropocene ${ }^{3}$ and its way

1 Grusin 2017.

2 Braidotti 2017, 21.

3 Alaimo 2016. 
of conflating all humans as equally responsible, various alternative names have been suggested for our predicament, like capitalocene, chthulucene, ${ }^{4}$ or even the planthroposcene ${ }^{5}$, the latter to indicate that humans need to recognize their deep interimplication with plants. Jussi Parikka's exploration of media theoretical deep time in his Anthrobscene ${ }^{6}$ is useful for a discussion of contemporary performance as well. For Parikka geology is relevant on the one hand as "the affordances that enable digital media to exist", that is, "a metallic materiality that links the earth to the media-technological". On the other hand, it is important as deep time, "the nonhuman earth times of decay and renewal" as well as to "the obscenities of the ecocrisis" taking place in "the anthrobscene." For Parikka, the Anthropocene is a radical environmental concept referring to "an environmentality understood and defined by the 'technological condition'". ${ }^{8}$ It expands from "natural ecology to an entanglement with technological questions, notions of subjectivity and agency" and criticizes a human-centered worldview, involving "accounts of rationality that are unable to talk about nonhumans as constitutive of social relations," ${ }^{9}$ a critique relevant when performing with plants. In Parikka's view, speaking of "[t]he anthropocene is a way to demonstrate that geology does not refer exclusively to the ground under our feet", but "is constitutive of social and technological relations as well as environmental and ecological realities". ${ }^{10}$ For him, "the addition of the obscene is self-explanatory", considering "the unsustainable, politically dubious, and ethically suspicious practices that maintain technological culture and its corporate networks." ${ }^{11}$ By using the form 'anthrobscene' he wants to "emphasize what we knew but perhaps shied away from acting on", namely, the "human-caused drive toward a sixth mass extinction of species."12

In this text we can, on the one hand, follow Parikka in thinking of the "obscene" character of wallowing in apocalyptic visions of human extinction as if that could somehow compensate for the sixth extinction of other species brought about through human invasion and pollution. On the other hand, we can refer to the historical roots of the word - ob skene - or off-stage, where the atrocities of the Greek tragedies took place, unseen by the audience, who only received reports by the various eloquent messengers reciting them in poetic verse. Many of the disasters of the Anthropocene take place literally off-stage, out of sight, often in remote areas, or then invisibly right in front of our eyes. We could understand the term even more literally, as referring to performance practices that take place off-stage in a conventional sense, outdoors and often out of sight, on the border of what is usually understood as performance. This is true at least for the case that will serve as our material and starting point

\footnotetext{
4 Haraway 2016.

5 Myers 2017.

6 Parikka 2014.

7 Parikka 2014, 62-63.

8 ibid., 73.

9 ibid., 73-74.

10 ibid., 74.

11 ibid., 17.

12 ibid., 18.
} 
in exploring the notion, a series of performances taking place as part of the project Performing with Plants.

II.

One context for this exploration, as well as for the project itself, is the growing interest in plant studies, which is, to some extent, a further development of the burgeoning of animal studies ${ }^{13}$ and post-humanist thinking ${ }^{14}$. Discussions have focused on plant rights ${ }^{15}$, plant philosophy or plant thinking ${ }^{16}$, plant theory ${ }^{17}$, the language of plants ${ }^{18}$ and queer plants. ${ }^{19}$ There is a current "plant turn" 20 in science, philosophy and environmental humanities, with an abundance of popular accounts of recent scientific research on plant sentience, intelligence and communication. ${ }^{21}$ An emerging field of critical plant studies ${ }^{22}$ can be linked to 'art's return to vegetal life'23 and to looking at plants in art. ${ }^{24}$ Discussions on plants and performance, however, are mostly linked to ecology in broader terms, ${ }^{25}$ with some exceptions like an interest in "vegetalized performance" ${ }^{26}$, and some attempts at performing with trees, junipers, pines, or thistles. ${ }^{27}$ There is no issue of Performance Research "On Plants", or "On Vegetation", yet.

A core challenge evoked by the current interest in the notion of the Anthropocene is exactly this: how to relate to other beings and entities with which we share this planet. And in terms of performance: how to perform with, include, or at least acknowledge the contribution of other beings than humans in our performances. ${ }^{28}$ Despite the flourishing research into plant sentience and the popular attention on the topic, there are a lack of studies on plants and performance. There is no way for a performer to know what a tree wants on anything but a very general level. How then to perform with plants and contribute to the development of something like a planthroposcene, ${ }^{29}$ a livable future for humans and plants?

We could distinguish several possible strategies when linking plants and performance - and most of these strategies could be extended to other lifeforms like fungi, bacteria etc. If we begin with a restricted understanding of

\footnotetext{
13 Derrida 2002; Haraway 2008.

14 Wolfe 2009; Braidotti 2013.

15 Hall 2011.

16 Marder 2013; Marder 2015; Irigaray and Marder 2016; Irigaray 2017.

17 Nealon 2016.

18 Kranz, Schwan, Wittrock 2016; Gagliano, Ryan and Vieira 2017.

19 Sandilands 2017.

20 Myers 2017.

21 Chamovitz 2017; Mancuso \& Viola 2015; Wohlleben 2016; Gagliano 2018.

22 Gibson \& Brits 2018.

23 Gibson 2018.

24 For example, Antennae 2011 Issue 17 Summer and Issue 18 Autumn, or Aloi 2018.

25 For example, Performing Ethos, Volume 5 (2015) or Performance Research: On Ecology

(2012).

26 Nicolić \& Radulovic 2018.

27 Arlander 2010; 2015; 2018a; 2018b; 2019.

28 For a discussion of ethics in interspecies performance, see Cull 2019.

29 Myers 2017.
} 
performance, where performers and spectators are easily distinguished, we have at least two options:

1. Plants perform for humans. This could take place simply in the display of flowers and fruits, ${ }^{30}$ in the sonification of their life processes, ${ }^{31}$ or by trees drawing with the help of specific tools. ${ }^{32}$

2. Humans perform for plants. Besides the notorious examples of playing music for plants to increase their growth, there are less instrumental contemporary performance projects like Dance for Plants. ${ }^{33}$

If we want to endorse a more theatrical understanding of performance, which often involves performing as somebody else, we can add two more strategies:

3. Humans perform as plants. Historical examples include Loie Fuller's choreographies on floral themes. ${ }^{34}$

4. Plants perform as humans. Vegetation can act as material for sculptures of humans as in Mathilde Roussel's Lives of Grass. ${ }^{35}$

To these strategies, we can add a fifth category, that is "performing with", which can be divided into several types depending on location:

5. Plants perform with humans.

a) In human spaces of display, like on stage or in a gallery. Examples abound: Essi Kausalainen performing with her house plants ${ }^{36}$, or Paul Rae and Kaylene Tan performing with a bonsai in Tree Duet. ${ }^{37}$ A provocative example of collaboration is Spela Petric's endurance performance Skotopoiesis, ${ }^{38}$ where the shadow of the standing artist is slowly formed on growing water cress.

b) In places where plants grow, like forests and fields. Aerial dancers like Anna Rubio ${ }^{39}$ perform with trees, activists live in trees to prevent them from being felled..$^{40}$ In the participatory performance Standing with the Saguaros, audience members were invited to stand with a saguaro cactus in the desert and document their experiences. ${ }^{41}$

\footnotetext{
30 Pollan 2002.

31 See for example Maeder $(2014,2015)$.

32 See for example Närhinen (2000).

33 Dance for Plants research collective (2016).

34 Such as Violet (1892), The Flowers (1893), and Une Pluie de fleurs (1898) by Fuller, mentioned in Schwan $(2016,271)$

35 Roussel (2010).

36 In her recent work, like My name is Monstera (2019) Kausalainen invites other people to perform.

37 Davis 2011, 55.

38 Petrič (2015).

39 For example in All the Trees I met, Rubio (2014-2016).

40 Philp 2018.

41 Eisele 2014.
} 
c) Entangled as part of the same organism, as in some forms of bio art. An astounding example is the "plantimal" called Edunia by Eduarco Kac, a genetically engineered flower, a hybrid of the artist and a Petunia. ${ }^{42}$

The examples of performing with plants we are going to look at in this text belong to category $5 \mathrm{~b}$, performing with plants in places where they grow - and in a mundane, somewhat unspectacular manner.

III.

The following examples of performing with trees, or tree stumps, were part of the project Performing with Plants at Stockholm University of the Arts, described in the plan as follows: "Performing with plants" is an artistic research project, which develops and specifies the question how to perform landscape today. A new materialist and post-humanist perspective prompt us to rethink the notion of landscape and to consider how the surrounding world consists of creatures, life forms, and material phenomena with varying degrees of volition, needs and agency. What forms of performing or activating landscape could be relevant in this situation? One possibility is to approach individual elements in a landscape, such as specific trees, and explore what can be done together with them, for instance how to perform for camera together. Rethinking our relationship to the environment is a central task for artists today. Artistic research can contribute through its capacity to allow and to generate hybrid forms of thinking and acting. This project participates in the discussion by way of a) developing artistic practices and producing art works that can critically question existing conventions and habits in our relationship to the environment and $b$ ) by theoretically reflecting, based on practical exploration, what it means to collaborate with plants and especially trees. The importance of the project rests ultimately on the importance of the plants themselves they are producing the preconditions for oxygen-based life on the planet." 43 The performances took place during the year 2018, the Chinese year of the dog, that is to say between 16 February 2018 and 3 February 2019, in LillJansskogen or Little Jan's Wood in the centre of Stockholm, between the campuses of the Royal Institute of Technology and Stockholm University. Four sites were visited repeatedly, two spruce stumps and two pine trees, sometimes three times a week. The performances were recorded by a video camera on a tripod to be edited into rough time-lapse videos. Removing the entering and the exiting from the image creates an impression of a continuous action or pose. Two of these performances are here analysed, namely, sitting on the two spruce stumps, while encounters with the pine trees have been discussed elsewhere. ${ }^{44}$ At the first site, I sat on an old spruce stump with the felled trunk still attached to it, relatively close to the camera (Fig 1.). At the second site, I sat on a small spruce stump on the ground among tall spruces, this time further away from the camera (Fig. 2.) In both performances, I was

42 Kac 2011.

43 Arlander 2016. 
wearing a pale pink woollen scarf and had my back turned to the camera. These repeated visits could be analysed as performances on several levels: in terms of repetition as a mode of performing, in terms of site-specific performances for occasional passers-by in urban space, in terms of posing for the camera as a silent witness and placeholder for future viewers, or in terms of appearing with plants in a more general sense. While individual poses form surprise performances for the passers-by, repeated visits form a recurring and therefore recognizable performance for the frequent users of the area. Moreover, they have performative power while functioning as a habitforming activity for the performer. The video recording serves as a selective documentation of the live event or, as a mode of gathering and preparing material for the videos as performance. The activity of editing is a performance as well, albeit not publicly displayed as one. Presenting the edited video in various contexts and circumstances as well as online are performances in their own right. The weekly documentation of the process with still images and blogposts on the project website ${ }^{45}$ online could be called an artistic research performance. And finally, writing an account of the process and the videos here, forms an academic performance as well. In this context, however, our main focus is the performance on the level of the video images. Posing for the camera together with the tree stumps is a way of appearing together, not only in the woods but in the image space.

The most important performance, on the level of the Anthropocene, or planthropocene, is probably the exchange of oxygen, carbon dioxide, and other chemicals that we perform, not only the spruces and me, but the rest of the surrounding vegetation as well. We could call them trans-corporeal exchanges, using the term coined by Stacy Alaimo. ${ }^{46}$ She understands "human corporeality as trans-corporeality, in which the human is always intermeshed with the more-than-human world", and by doing that she "underlines the extent to which the substance of the human is ultimately inseparable from 'the environment'." 47 Trans-corporeality emphasizes "movement across bodies" and "reveals the interchanges and interconnections between various bodily natures". ${ }^{48}$ Alaimo notes that it is also helpful in cultivating "a tangible sense of connection to the material world in order to encourage an environmentalist ethos" and to counteract the tendency to disconnect and treat "environmental issues' as containable, eccentric, dismissible topics." 49

In the following, when looking at these examples with Braidotti's four theses in mind, we are not focusing on trans-corporeal exchanges, however, but rather staying on the level of the performance within the frame of the edited video, which of course is spatial and temporal. In the context of a journal it has to be communicated with still images, here, one of the first clips from each video.

45 Arlander 2016

46 Alaimo $2010,3$.

47 Ibid., 2.

48 Ibid., 2.

49 Ibid., 16. 


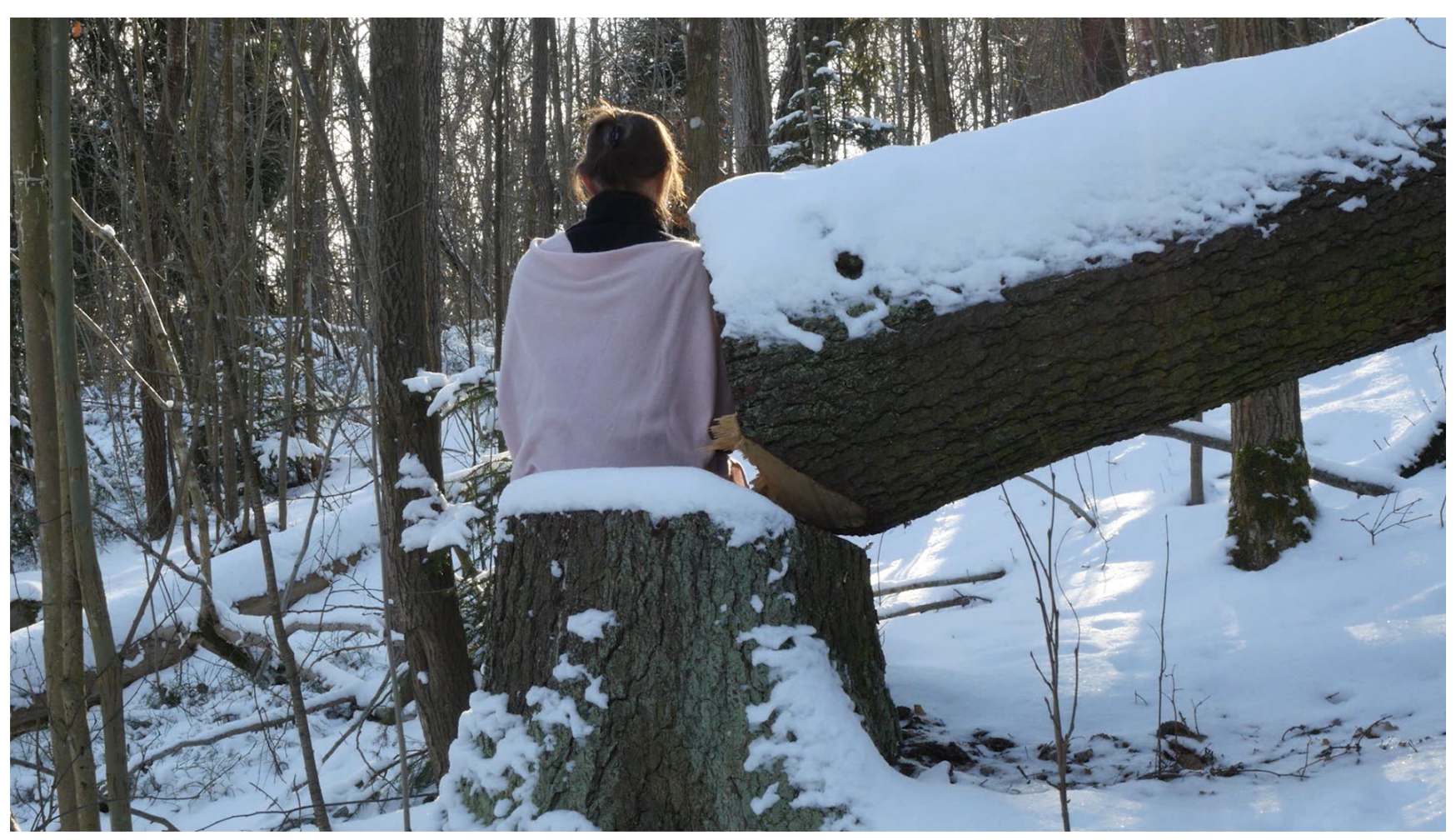

[Fig.1] Year of the Dog in Lill-Jan's Wood (On a Spruce Stump) 1

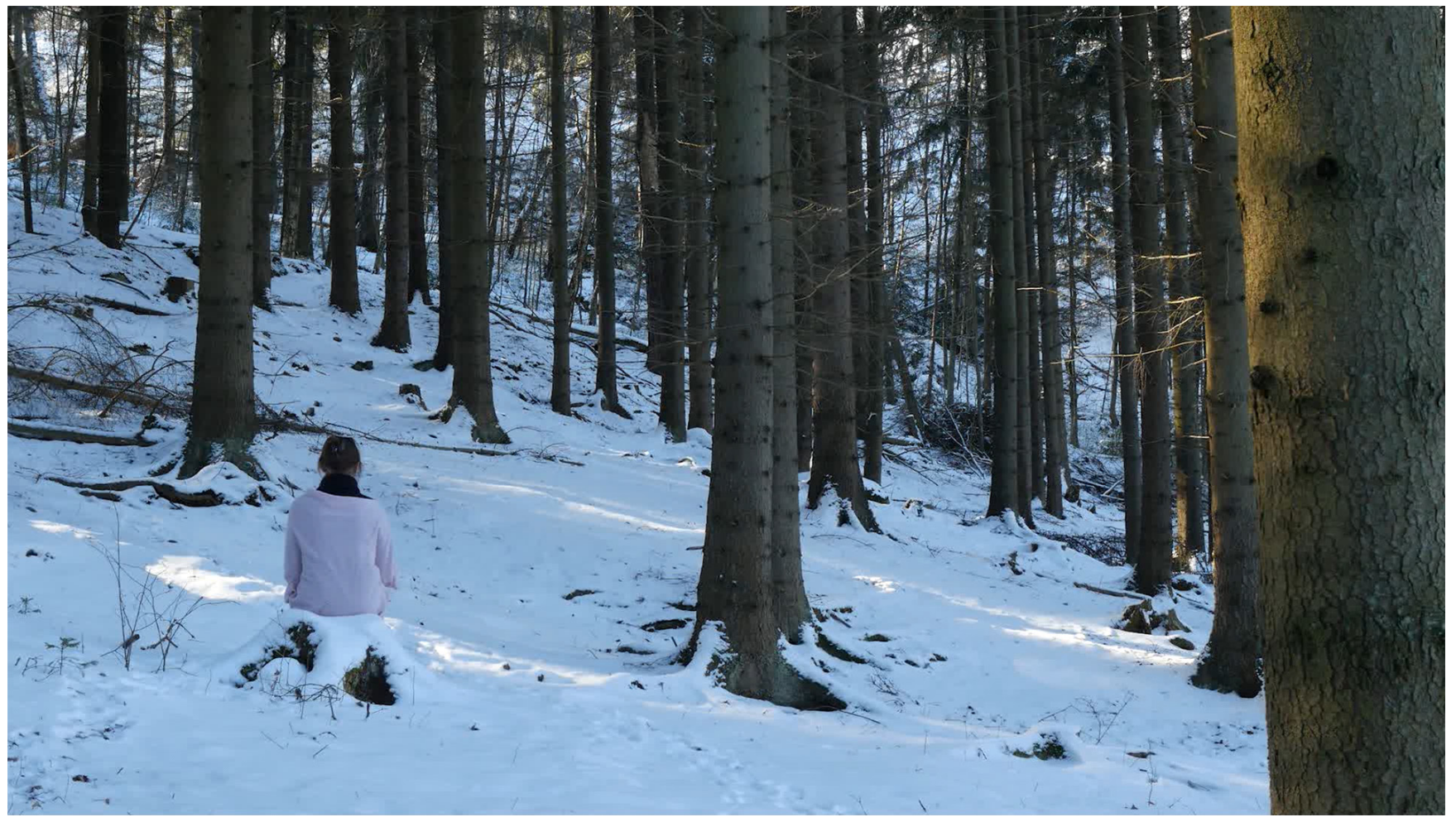

[Fig.2] Year of the Dog in Lill-Jan's Wood (On a Spruce Stump) 2 


\section{IV.}

Faced with such global problems as the climate crisis, performing with plants (or with anything else) might seem like the last thing to worry about. Let us nevertheless take a look at what Braidotti's theses might mean in terms of performance. We can also try the other way around and use Braidotti's four theses as an analytical tool. What can be understood of a performance practice with the help of these four theses, if we take them as aspects to explore in any specific work? Or transform them into analytical questions? In the following I will begin with a summary of each of Rosi Braidotti's "Four Theses on Posthuman Feminism".

1. "Feminism is not a humanism." 50 Braidotti notes that emancipatory political struggles have tended to rely on ideas of equality that assume an unproblematized universal humanity. ${ }^{51}$ Even for Marxism, 'man' was the social and cultural evolutionary driving force. ${ }^{52}$ European humanism and western modernity, 'man' as the measure of all things, have been challenged, questioned and criticized by many social and theoretical movements, and also by the "master of high antihumanism Michel Foucault". ${ }^{53}$ Braidotti notes how feminist and postcolonial analyses have helped us see the historical roots and the partiality of the supposedly universal category of the "'Man of reason"”. ${ }^{4}$ After the feminist critique of "abstract masculinity, triumphant whiteness and hegemonic able-bodiedness", she adds, it is not possible to speak of any category as unified, including women, indigenous people or other marginalized subjects; each subject-position must be understood as internally fractured by "the 'difference within'". ${ }^{55}$ Braidotti reminds us of Donna Haraway's suggestion that "some differences are playful, but others are poles of world-historical systems of domination", and "[f]eminist epistemology is about knowing the difference." 56 It is also possible to see humanism as a project to be completed; one can criticize humanism in the name of humanism, following Edward Said, she notes. Although some neohumanists, like ecofeminists, propagate diversity ${ }^{57}$ too, for Braidotti feminism is nevertheless resolutely antihumanist in rejecting Eurocentric nationalistic humanism. ${ }^{58}$

Thinking of alternative strategies in performance in response to Braidotti's first thesis, "feminism is not a humanism", is relatively easy. Performances criticising the Eurocentric views of traditional humanism or performances with a feminist, queer, de-colonial or anti-racist agenda are conceivable. Theatre is relatively well suited for staging debates along these lines. Performance art with its focus on the artist's body has been a central tool for performances of

50 Braidotti 2017, 21.

51 lbid.

52 Ibid., 22.

53 Ibid.

54 Ibid., 22-23.

55 Ibid., 24.

56 lbid.

57 Ibid., 25.

58 Ibid. 
various types of identity politics. In terms of analysis, the statement "feminism is not a humanism" could be transformed into the question: Are there humans involved in the performance and are they conceived in universalist terms? What is their role or character and action?

2. "Anthropos is off-center." ${ }^{59}$ Debating against humanism seems easier than overcoming anthropocentrism, ${ }^{60}$ Braidotti notes. She recognizes how the humanities are in some sense constituted by anthropocentrism and have problems with adopting the temporal and spatial scales of planetary and deep time perspectives and a geocentered rather than anthropocentric frame? ${ }^{61}$ If the humanities have trouble transforming into posthumanities, theatre and performance are no better off. The task is not only empowering the sexualized and racialized human 'Others', now "[a]nimals, insects, plants, cells, bacteria, in fact the planet and the cosmos, are turned into a political arena." ${ }^{2}$ Decentering the human challenges "the separation of bios, as exclusively human life, from zoe, the life of animals and nonhuman entities." 63 We are left with a continuum of human and non-human lives including various forms of technological mediations. ${ }^{64}$ Braidotti notes how Haraway set a new agenda already in the mid 1980's with her Cyborg manifesto, rejecting anthropocentrism for relational connections between human and nonhuman others or technological artifacts. She tried to unhinge the link between women or non-Europeans and nature and point at the necessity of a feminist and anti-racist critique that could embrace an understanding of the nature-culture continuum as technologically mediated. ${ }^{65}$ Braidotti acknowledges that disidentifying from anthropocentrism can be hard and requires complex relationalities. ${ }^{66}$ As a way of moving forward, Braidotti nevertheless argues for "an activist embrace of zoe: nonhuman life." 67

What the second thesis, "anthropos is off-center", might mean in terms of performance is harder to fathom. Humans are usually very much in focus in most forms of performance. There are examples of shows without human performers on stage ${ }^{68}$ and performances where animals play a prominent part, but they are exceptions to the rule. In puppet theatre there need be no humans on stage, but humans are depicted by the puppets. Many groups striving to include a non-human or more-than-human perspective, like the Finnish group Other spaces, ${ }^{69}$ evoke other-than-human entities using the human body as a tool and penetrate into unknown worlds with the help of human imagination. Thus, human bodies, of both performers and participants, remain very much

59 Braidotti 2017, 26.

60 Braidotti 2017, 26.

61 Braidotti 2017, 27.

62 Braidotti 2017, 26.

63 Braidotti 2017, 26.

64 Braidotti 2017, 26.

65 Braidotti 2017, 28.

66 Braidotti 2017, 30.

67 Braidotti 2017, 30.

68 See for example van Baarle (2016).

69 Toisissa Tiloissa - Other Spaces https://toisissatiloissa.net/en/ 
at the centre of attention. Displacing Anthropos from centre-stage is not easy. Using Braidotti's terms, we could say that humans remain anthropomorphic even when not explicitly anthropocentric. The statement "anthropos is offcenter" could be reformulated as a question: Are humans in the centre or in focus in the performance? What is their relationship to other beings or elements that receive attention?

3. "Zoe is the ruling principle."70 Embracing zoe is not without risks because advanced capitalism is actually decentering anthropocentrism through techno-scientific networks, Braidotti warns. ${ }^{71}$ These "investments in 'life' as an informational system", with ongoing "biotechnological intervention upon humans, animals, seeds, cells, and plants" strive for "scientific and economic control and the commodification of all that lives."72 Thus, the power of information in living matter constitutes capital value. ${ }^{73}$ As a response to this situation, Braidotti proposes "species egalitarianism" because "we are all part of something we used to call 'nature"', embodied and embedded, despite the supposed transcendental qualities of human consciousness. ${ }^{74}$ She proposes alliances across species in terms of "the productive and immanent force of zoe, or life in its non-human aspects." ${ }^{75}$ For her, zoe stands for a dynamic, selforganising generative vitality. ${ }^{76}$ Braidotti explains her philosophical position by referring to Spinozist monism as a form of "dynamic, nonessentialist, and relational brand of materialist vitalism" which enables thinking of difference not as dichotomies but rather as rhizomatics, as processes of differing instead of binaries like sex-gender or nature-culture. ${ }^{77}$ She speaks for a zoe-centered and nonanthropocentric relational ontology, without denying "the anthropologically bound structure of the human."78 Acknowledging that our specific embodied and embedded situation is to be anthropomorphic is the first step toward overcoming anthropocentrism, she notes. ${ }^{79}$ Such a distinction between anthropomorphism, having a human form, and anthropocentrism, being human-centred, is relevant for the performing arts. The posthuman subject has relational capacities beyond our species, Braidotti notes, because living matter, such as human flesh, is connected to the rest of organic life and to animals and the earth, and therefore intelligent and self-organizing. ${ }^{80}$ And to vegetation, we should add, to plants, which we are completely dependent on, both for our nourishment and for the air we breathe. For Braidotti, the core of the postanthropocentric turn is a zoecentered egalitarianism because it offers a "materialist, secular, grounded, and

70 Braidotti 2017, 31.

71 lbid.

72 lbid.

73 lbid.

74 Ibid., 32.

75 Ibid.

76 Ibid.

77 Ibid., 34 .

78 Ibid., 32.

79 Ibid.

80 Ibid., 33. 
unsentimental response to the opportunistic transspecies commodification of life that is the logic of advanced capitalism." ${ }^{11}$ We must acknowledge, however, that although life is zoe driven and geocentered, she notes, for humans it is necessarily to be "anthropomorphic, that is to say, embedded and embodied, enfleshed, affective, and relational." 82 We can become creatively zoe-centered only by embracing our anthropomorphic limits, she adds. ${ }^{83}$

The third thesis, "zoe is the ruling principle", is perhaps the most relevant when discussing performing with plants. Any type of working with the vegetal entails acknowledging our common participation in zoe. In their persistent growth, plants are living demonstrations of zoe as life force. This thesis is also the one that resonates the most with the works with spruce stumps and pine trees that I use as examples. Becoming zoe-centered is nevertheless easier said than done, as we shall see. The claim "zoe is the ruling principle" suggests us to ask: Are other life-forms present or presented in the performance and in what manner?

4. "Sexuality is a force beyond gender." ${ }^{84}$ According to Braidotti, contemporary capitalism is a "postgender system" that can accommodate androgyny and a blurring of the sex divide to a large extent.$^{85}$ This is not to deny the fact, she adds, that on a world scale, sexual and gender differences are polarized, perhaps even stronger than before. ${ }^{86}$ Current capitalism is also post-racial in the sense of not classifying people or cultures based on skin pigmentation, but remains nevertheless profoundly racist. ${ }^{87}$ Braidotti suggests that we should rethink sexuality without genders, and return to "the polymorphous and, according to Freud, 'perverse' (in the sense of playful and nonreproductive) structure of human sexuality." 88 Sexuality is the vital force that is captured, inscribed, and caught into a sex-gender dichotomy, ${ }^{89}$ but it is not reducible to it. ${ }^{90}$ For Braidotti, gender as a form of governance should be disrupted by becoming-woman, becoming minoritarian, or becoming imperceptible. ${ }^{91}$ Or, by becoming plant, perhaps $?^{92}$ She suggests that we experiment with intensities and with zoe in order to discover what posthuman sexed bodies could become. ${ }^{93}$ Braidotti emphasizes a nonessentialistic concept of difference, and sees the principle of differing as constitutive of the posthuman subject as well as for ethical accountability in a postanthropocentric sense. ${ }^{94}$ She urges us to acknowledge

81 Braidotti 2017, 32.

82 Braidotti 2017, 35.

83 Braidotti 2017, 35.

84 Braidotti 2017, 35.

85 Braidotti 2017, 35.

86 Braidotti 2017, 38.

87 Braidotti 2017, 35.

88 Braidotti 2017, 36.

89 Braidotti 2017, 37.

90 Braidotti 2017, 36.

91 Braidotti 2017, 37.

92 Houle 2011, 95.

93 Braidotti 2017, 38.

94 Braidotti 2017, 38. 
the multiple ties that bind us to various others in complex relations. ${ }^{95}$ Such ethical relationality destroys all fantasies of unity, totality, and oneness, she adds, but it also demolishes oedipalized narratives of irreparable loss, lack, and separation. ${ }^{96}$ In an affirmative manner, Braidotti stresses the generative power of relations and reminds us of "the flows of encounters, interactions, affectivity and desire" that difference as positivity entails. ${ }^{97}$

The fourth thesis, "sexuality is a force beyond gender", is also relevant for much performance practice, which usually utilizes and intensifies affects and desires. And it is deliberately played with and explored by performance artists such as Annie Sprinkle and Elisabeth Stevens and their SexEcology project, in Ecosex weddings to natural entities, like Wedding to the Dirt, which sounds decidedly plant-like. ${ }^{98}$ The thesis, "sexuality is a force beyond gender", could challenge us to ask more generally: What role does sexuality or gender play in the performance? How is vitality expressed?

\section{V.}

Considering the performances with spruce stumps, what can we learn about them with the help of these theses, and the questions derived from them? To begin with, we can ask: Are humans involved in the performance and are they conceived in universalist terms? What is their role or action?

There is a human figure in a very dominating role in the images, sitting on a spruce stump, either relatively close to the camera (in the first image) or as a smaller figure among the trees (in the second image). It is perhaps not obvious that it is a woman because she sits immobile with her back to the camera, but the pale pink scarf and the hairstyle would probably serve as indicia enough for many spectators. We could even think of the statement by John Berger about men looking at women, women watching themselves being looked at, turning themselves into an object of vision, a sight. ${ }^{99}$ Although the human figure is seated with her back to us in the manner of the rückenfiguren in German romantic painting, ${ }^{100}$ leading the viewer's gaze into the landscape, this could also be understood as a gesture to downplay the individual characteristics and the importance of the human figure, as a tool for off-setting the human. By abstracting the human figure into "a human figure", a universalising tendency is at play, a disregard of the specifics of race, gender, age, location, and more.

Secondly: Are humans in the centre or in focus in the performance? What is their relationship to other beings or elements that receive attention?

The human figure, the Anthropos in these images, is not off-center, but actually very much in focus, despite her immobility, or perhaps actually because of it. In the first image, the seated figure covers a large area of the image space, and even though the huge felled spruce she is sitting on probably catches much

95 Braidotti 2017, 38.

96 Ibid.

97 Ibid.

98 Stevens and Sprinkle (2014).

99 Berger quoted in Alaimo 2016, 75.

100 Andrews 1999, 143. 
of the attention, the human figure is certainly not off-center. The fact that the spruce, with its diagonal trunk, is given some prominence could be understood as an attempt at changing that. The huge trunk could also serve as a reminder of the devastating effects of human activities in the forest, although in this case it is probably left lying in the wood to promote biodiversity by providing nourishment for various insects, fungi, and other creatures. The gesture of sitting on the stump is actually rather morbid if we think of the tree as a living being or "person"; 101 why sit on a corpse? In the second image, the human is literally off-center to the left and much smaller, but nevertheless provides the focal point or "argument" of the image. ${ }^{102}$ She plays the leading role as some kind of fairy-tale character, with the spruces serving as the backdrop, the dark forest she is lost in, or whatever other narrative we want to develop around the composition.

Thirdly, what about zoe? Are other life-forms present or presented in the performance and in what manner?

Although the human presence is rather dominating in these images (more than was intended, actually) the images in some sense depict zoe, the vital processes underway. By repeating the same framing of the image from one video clip to the next, and by thus highlighting the temporal changes in the environment across the seasons, the growth principle in the environment is made visible. During the summer months the small rowan growing in the foreground in the first image momentarily takes centre stage, when its leaves fill the image space, partly covering the human figure. Moreover, the bark of the spruce trunk that slowly peels off and then has suddenly fallen to the ground provides an action beyond the human. By remaining immobile, the human figure gives space for other actors or agents to move. By her stillness she is allowing and participating in the rhythms of zoe.

And lastly: What role does sexuality or gender play in the performance? How is vitality expressed?

It is perhaps difficult to see any open sexuality or desire in these images, although we can assume that there is a lot of sexuality in the sense of vital life force involved in the growth and decay in the woods. The question of the gender of the human figure was already discussed in relation to humanism. The human wish or need to partake in zoe, in an exchange with other beings in the environment, for good or bad, depending on the particular agents involved (mosquiteos, bacteria etc.) could be understood as a sexual desire of sorts. The customary way of understanding sexuality through the gendered social system makes it difficult to conceive of our relationship to the environment as sexual. Affective exchange is definitely at play when returning to the same place and the same plants repeatedly for a year. All kinds of romantic overtones and emotional attachments could be imagined between the human and the tree as the notion "tree hugger" suggest. And as an experience of a shared life force, sexuality is omnipresent, as a will to breathe and grow, as sensual delight.

Of the four theses and the questions derived from them the third one - zoe is

101 Hall 2011.

102 Andrews 1999, 5. 
the ruling principle - is probably the most relevant for these examples. One way of describing the performances could be to note that the human figure performs her still-act with the tree stumps in order to help the viewer see the ongoing performance of zoe taking place around her over the year. Despite being anthropomorphic and, to some extent, anthropocentric through her presence, these videos are nevertheless first of all examples of zoe performing.

VI.

Are these four theses useful beyond their possible use as analytical tools when trying to understand what performing with plants might mean? Braidotti envisions a community held together, not by negative bonds of shared vulnerability, ancestral violence or unpayable debts, but rather joined by compassion and acknowledgement of interdependence with others, which, in the age of the Anthropocene, are mostly not anthropomorphic. ${ }^{103}$ Nor have they been that in any other era, as far as we know. Braidotti suggests, however, that we should resist a too easily formulated cosmopolitanism. ${ }^{104}$ Besides being postanthropocentric, unifying all life forms under the demands of the market, the global economy is also neohumanistic, creating new human alliances based on fear, she notes. ${ }^{105}$ For Braidotti this means that the posthuman is not postpolitical but relational; environmental issues necessarily involve both human and nonhuman forces. ${ }^{106} \mathrm{~A}$ community with plants?

The problem of performing with plants could be considered via a dualistic world view as an encounter with "the Other" that remains forever incomprehensible, beyond reach, irrevocably different, and demanding our respect for that difference. There is no way to enter into a dialogue on equal footing with a spruce, even less with a spruce stump. Thinking of trees as such ultimate others is only one possibility, however. Recent scientific studies of plant behaviour and plant genetics have revealed that we share a lot of life processes with plants due to our common descent from one-cell organisms. Moreover, plants seem to have capacities earlier thought of as the sole capacity of humans, or later animals, like associative learning and some form of memory. ${ }^{107}$ Therefore, Braidotti's monist ontology, with a continuum between the human and the nonhuman, where differences are rhizomatic rather than dualistic, and her idea of zoe rather than bios as the ruling principle, makes more and more sense. The relationality with non-human entities is crucial here. However much we would think of ourselves as being a geological force, the masters and culprits of the obscene Anthropocene, the leading characters performing in a morbid spectacle, we are not the only ones involved.

The notion Planthroposcene, proposed by anthropologist Natasha Myers (2017), is a reminder to put our self-importance into perspective and a useful complement to Braidotti's theses when we consider performing with plants.

103 Braidotti 2017, 39.

104 Ibid.

105 Ibid.

106 Ibid., 40.

107 Mancuso \& Viola 2015; Chamovitz 2017; Gagliano et al. 2017. 
Myers notes that whether one locates the origin of the Anthropocene "at the invention of agriculture" or at "the ravages of colonialism", with "the industrial revolution and the vast expansion of plantation agriculture and forms of accumulation by dispossession", or links it to "petrocapitalism's extractive 'exuberance'” or to "agriculture's chemical and industrial revolutions", all these have had "devastating consequences for both plants and their people."108 What she, "half cheekily and half seriously", calls the Planthroposcene, "is an aspirational episteme and way of doing life in which people come to recognize their profound interimplication with plants". ${ }^{109}$ The Planthroposcene "does not name a time-bound era", ${ }^{110}$ but is rather "a call to change the terms of encounter, to make allies with these green beings," "111 she notes.

Although Myer's focus is on gardens and garden design, her analysis is relevant for other performances with plants. "A well-tended garden, whether in a bucket or on board a space station, provides a stage for plants and people to perform their entangled powers." 112 Gardens show "the various ways that people stage relations with plants - whether ... intimate, extractive, violent, or instrumentalizing." 113 The same could be said of parks, woods, and why not performances in parks, too. The examples discussed above could be recognized as intimate rather than violent or extractive, but they are nevertheless also instrumentalizing to some extent. Sitting on a spruce stump means using it as a supporting structure, and posing for a camera on a tripod with it (without asking for consent) are both performances that utilize the stump or the plant in some manner, although trying to let them be as they are and where they are. There are no exchanges of mutual benefit taking place comparable with gardening.

Myers plays with the words 'seen', and 'scene' and "the ways some garden designs have the potential to stage both new scenes of, and new ways to see (and even seed)" "114 collaborations between people and plants. She is interested in attempts "that stage livable futures for both plants and people." 115 Her use of words like 'staging' prompts us to consider how this could be done in and with performance. And her explicit reminder that "we are of the plants; that our futures hinge on creating liveable futures with the plants"116 might help us in remembering the importance of doing that.

With the questions generated from Braidotti's four theses on posthuman feminism, we can return to the problems we began with; could they help us in analysing the performances of the obscene Anthropocene? Perhaps, possibly... By way of concluding I repeat them here, with the hope that others might try them out:

\footnotetext{
108 Myers 2017, 2.

109 Ibid., 3.

110 lbid., 3.

111 Ibid., 4.

112 Ibid., 1.

113 Ibid., 1.

114 Ibid., 4.

115 lbid., 3.

116 Ibid., 3.
} 
Are humans involved in the performance and are they conceived in universalist terms; what is their role and action?

Are humans in the centre or in focus in the performance; what is their relationship to other beings or elements that receive attention?

Are other life-forms present or presented in the performance and in what manner?

What role does sexuality or gender play in the performance; how is vitality expressed?

And finally, with Myer's challenge to stage livable futures for plants and people, we can return to the question of performing with plants: Could exploring ways of performing with plants mitigate the anthropocentrism of performance art? Based on my experiences of sitting on spruce stumps I would like to reply with a tentative - yes, perhaps. 


\section{AUTHOR}

Annette Arlander, DA, is an artist, researcher, and a pedagogue, one of the pioneers of Finnish performance art and a trailblazer of artistic research. In 2018-2019 she was professor in performance, art, and theory at Stockholm University of the Arts. At present, she is visiting researcher at the Academy of Fine Arts University of the Arts Helsinki and the principal investigator of the Academy of Finland funded research project How to Do Things with Performance (2016-2020). Her research interests include artistic research, performance-as-research, site-specificity, and the environment. Her artwork moves between the traditions of performance art, video art, and environmental art.

\section{REFERENCES}

Antennae: The Journal of Nature in Visual Culture. 2011. Giovanni Aloi (ed.) Special issue, 'Why Look at Plants?' 17 (Summer).

Antennae: The Journal of Nature in Visual Culture. 2011. Giovanni Aloi (ed.) Special issue, 'Beyond Morphology' 18 (Autumn).

Aloi, Giovanni. 2018. (ed.). Why Look at Plants? The Botanical Emergence in Contemporary Art. Critical Plant Studies 5. Leiden, Boston: Brill Rodopi.

Alaimo, Stacy. 2010. Bodily Natures. Science, Environment, and the Material Self. Bloomington \& Indianapolis: Indiana University Press.

Alaimo, Stacy. 2016. Exposed. Environmental Politics and Pleasures in Posthuman Times. Minneapolis, London: University of Minnesota Press.

Andrews, Malcolm. 1999. Landscape and Western Art. New York: Oxford University Press.

Arlander, Annette. 2010. "Performing with Trees: Landscape and Artistic Research". In John Freeman (ed.) Blood, Sweat \& Theory - Research Through Practice in Performance. London: Libri Publishing, 158-176.

Arlander, Annette. 2015. “'Becoming Juniper'. Landschaft performen als künstlerische Forschung" [Becoming Juniper as Artistic Research]. In Erika Fischer-Lichte \& Daniela Hahn (eds.) Ökologie und die Künste. Paderborn: Wilhelm Fink Verlag, 141-157.

Arlander, Annette. 2016. "Performing with plants - Att uppträda/ samarbeta med växter" Research application, project website https://www.researchcatalogue.net/view/316550/316551 [accessed 01/05/2020]

Arlander, Annette. 2018a. "Performing with Plants". In Leena Rouhiainen (ed.) Perilous Experience CARPA 5 Colloquium Proceedings. Nivel 09 http://nivel.teak.fi/carpa5/annette- 
arlander-performing-with-plants/[accessed 01/05/2020]

Arlander, Annette. 2018b. "Breathing and Growth - performing with plants". Dance and Somatic Practices Issue 10.2, 175-187.

Arlander, Annette. 2019. "Resting with Pines in Nida - attempts at performing with plants." Performance Philosophy Vol 4, no 2, 452-475. https://doi.org/10.21476/PP.2019.42232 [accessed 01/05/2020]

Arlander, Annette. 2020. "Visiting a Tree". In Maiju Loukola, Mari Mäkiranta, VOICES ruukku peripheries/katveet issue: FLOATING PERIPHERIES Conference 2019 - Sites and Situations (2020) https://www.researchcatalogue.net/view/757632/757633/0/0 [accessed 01/05/2020]

Braidotti, Rosi. 2013. The Posthuman. Oxford, UK: Polity Press.

Braidotti, Rosi. 2017. "Four Theses on Posthuman Feminism". In Richard Grusin (ed.) Anthropocene Feminism. Minneapolis \& London: University of Minnesota Press, 21-48.

Chamovitz, Daniel. 2017. What a Plant Knows. A Field Guide to the Senses. Updated and expanded edition. New York: Scientific American / Farrar, Straus and Giroux.

Cull, Laura. 2019. "The Ethics of Interspecies Performance: Empathy beyond Analogy in Fevered Sleep's Sheep Pig Goat” Theatre Journal. Volume 71, Issue 3, September 2019 https://www. jhuptheatre.org/theatre-journal/online-content/issue/volume-71-number-3-september-2019/ ethics-interspecies [accessed 01/05/2020]

Dance for Plants research collective. 2016. http://www.danceforplants.com [accessed 01/05/2020]

Davis, Lucy. 2011. "In the Company of Trees." Antennae: The Journal of Nature in Visual Culture. 17 (Summer), 43-62.

Derrida, Jacques. 2002. "The Animal That Therefore I Am (More to Follow)." Translated by Davis Wills. Critical Inquiry, Vol. 28, No. 2. (Winter, 2002), 369-418.

Eisele, Kimi. 2014. "How to Duet with a Saguaro". Performing Ethos Volume 5. Numbers 1\&2, 53-64.

Eisele, Kimi \& Borderlands Theater. 2016. Standing with the Saguaros https:// standingwithsaguaros.org [accessed 01/05/2020]

Gagliano, Monica. 2018. Thus Spoke the Plant. A Remarkable Journey of Groundbreaking Scientific Discoveries and Personal Encounters with Plants. Berkeley, California: North Atlantic Books.

Gagliano, Monica, John C. Ryan and Patricia Viveira. (eds.) 2017. The Language of Plants Science, Philosophy, Literature. Minneapolis London: University of Minnesota Press.

Gibson, Prudence. 2018. The Plant Contract: Art's Return to Vegetal Life. Critical Plant Studies 
3. Leiden, Boston: Brill Rodopi.

Gibson, Prudence and Baylee Brits (eds.) 2018. Covert Plants. Vegetal Consciousness and Agency in an Anthropocentric World. Santa Barbara, CA: Brainstorm Books.

Grusin, Richard. (ed.) 2017. Anthropocene Feminism. Minneapolis \& London: University of Minnesota Press.

Hall, Matthew. 2011. Plants as Persons. A Philosophical Botany. New York: Suny Press.

Haraway, Donna J. 2008. When Species Meet. Minneapolis: University of Minnesota Press.

Haraway, Donna J. 2016. Staying with the Trouble: Making Kin in the Chthulucene. Durham and London: Duke University Press.

Houle, Karen L. F. 2011. "Animal, Vegetal, Mineral: Ethics as Extension or Becoming? The Case of Becoming Plant." Journal for Critical Animal Studies, Volume IX, Issue 1/2, 89-116.

Irigaray, Luce. 2017. "What the Vegetal World Says to Us". In Monica Gagliano, John. C. Ryan and Patricia Viveira (eds.) 2017. The Language of Plants - Science, Philosophy, Literature. Minneapolis London: University of Minnesota Press, 126-135.

Irigaray, Luce and Michael Marder. 2016. Through Vegetal Being. Two Philosophical Perspectives. New York: Columbia University Press.

Kac, Eduardo. 2011. "Natural history of the Enigma". Antennae: The Journal of Nature in Visual Culture. 18 (Autumn), 85-89.

Kausalainen, Essi. 2019. My name is Monstera https://madhousehelsinki.fi/events/ Monstera?locale $=$ en [accessed 01/05/2020]

Kranz, Isabel, Alexander Schwan, and Eike Wittrock (eds.) 2016. Floriographie. Die Sprachen der Blumen. Paderborn: Wilhelm Fink Verlag.

Maeder, Marcus. 2016. "Trees: Pinus sylvestris." Journal for Artistic Research, 11 https://www. researchcatalogue. net/view/215961/215962/0/0 [accessed 01/05/2020]

Mancuso, Stefano and Alessandra Viola. 2015. Brilliant Green. The Surprising History and Science of Plant Intelligence. Washington: Island Press.

Marder, Michael 2013. Plant-Thinking: A Philosophy of Vegetal Life. New York: Columbia University Press.

Marder, Michael. 2015. "The Place of Plants: Spatiality, Movement, Growth." Performance Philosophy Vol 1, 185 $\square$ 194. http://www.performancephilosophy.org/journal/article/view/28 [accessed 01/05/2020]

Myers, Natasha. 2017. "From the Anthropocene to the Planthroposcene: Designing Gardens for Plant/People Involution." History and Anthropology. http://dx.doi.org/10.1080/02757206.20 
Nealon, Jeffrey T. 2016. Plant Theory. Bio Power and Vegetable Life. Stanford, California: Stanford University Press.

Nikolić, Mirko and Neda Radulovic. 2018. "Aesthetics of inhuman touch: notes for 'vegetalised' performance." Ruukku 9, https://doi.org/10.22501/ruu.372629 _[accessed 01/05/2020]

Närhinen, Tuula. 2000. Windtracers. http://www.tuulanarhinen.net/artworks/wind.html [accessed 01/05/2020]

Parikka, Jussi. 2014. The Anthrobscene. Minneapolis: University of Minnesota Press.

Performing Ethos, Volume 5. Numbers 1- 2. July 2015.

Performance Research. 2012. Stephen Bottoms, Aaron Franks, and Paula Kramer (eds.) Special issue, 'On Ecology'. 17.4.

Petrič, Špela. 2015. Confronting Vegetal Otherness: Skotopoiesis http://www.spelapetric.org [accessed 01/05/2020]

Philp, Drew. 2018. "America's tree sitters risk lives on the front line." https://www.theguardian. com/environment/2018/may/26/tree-sitters-appalachian-oil-pipeline-virginia-west [accessed 01/05/2020]

Pollan, Michael. 2002. The Botany of Desire: A Plant's-eye View of the World. London: Bloomsbury Publishing.

Roussel, Mathilde. 2010. Lives of Grass https://anti-utopias.com/art/mathilde-roussel-lives-ofgrass/[accessed 01/05/2020]

Rubio, Anna. 2014-2016. All the Trees I met http://www.frontiersinretreat.org/activities/anna rubio all the trees i met [accessed 01/05/2020]

Sandilands, Catriona. 2017. "Fear of a Queer Plant?" GLQ: A Journal of Lesbian and Gay Studies, Volume 23, Number 3, 419-429.

Schwan, Alexander. 2016. "Wilting Flowers in Dance. Choreographic approaches to floral ephemerality." In Isabel Kranz, Alexander Schwan, and Eike Wittrock (eds.) Floriographie. Die Sprachen der Blumen. Paderborn: Wilhelm Fink, 259-285.

Stevens, Elizabeth and Sprinkle, Annie. (no date) Sexecology http://sexecology.org/\#[accessed 01/05/2020]

Toisissa Tiloissa - Other Spaces Live Art collective (2004) https://toisissatiloissa.net/en/ [accessed 01/05/2020]

Van Baarle, Kristof. 2016. "The Performer is Absent: Spaces of Absence in Contemporary Performing Arts". In Arlander, Annette. (ed.) The Non-human and the Inhuman in Performing 
Arts - Bodies, Organisms and Objects in Conflict. Proceedings of Carpa 4 - Colloquium on Artistic Research in Performing Arts. Nivel 6. https://nivel.teak.fi/carpa4/the-performer-isabsent-spaces-of-absence-in-the-contemporary-performing-arts-kristof-van-baarle/ [accessed 01/05/2020]

Wohlleben, Peter. 2016. The Hidden Life of Trees - What They Feel, How They Communicate - Discoveries from a Secret World. Vancouver, Canada: Greystone Books.

Wolfe, Cary. 2010. What is Posthumanism? Minnesota: University of Minnesota Press. 